\section{Social scientists join synthetic-biology centre}

The United Kingdom's first publicly-funded centre devoted to synthetic biology, which opened on 12 May, is hoping to pre-empt public concerns about the field by integrating social scientists into its research team.

Graduate students and staff at the Centre for Synthetic Biology and Innovation at Imperial College London will be trained to consider the social and ethical implications of their research. Sociologists on the staff will also work with government and industry to develop a suitable framework for regulating the products of synthetic biology, and for making intellectual-property claims.

"If the Imperial centre works, they're going to be setting the standard for this," says Pam Silver, a synthetic-biology researcher from Harvard University.

The Engineering and Physical Sciences Research Council is providing the centre with $£ 8$ million (US\$11 million) over the next 5 years.

For a longer version of this story, see http://tinyurl. com/pc4n9n.

\section{South Africa's cabinet a mixed bag for science}

Academics have welcomed the appointment of Naledi Pandor as science and technology minister in South Africa's new cabinet, announced on 10 May by President Jacob Zuma.

Pandor previously headed the education department, but some say she may lack the scientific know-how of her predecessor, mathematician Mosibudi Mangena.

Many researchers had hoped Zuma would retain Barbara Hogan, the respected health minister whose appointment in September 2008 signalled a reversal of the government's denial that HIV causes AIDS.

Instead, Hogan was transferred to public enterprises, and replaced by Aaron Motsaledi, a little-known physician. For a longer version of this story, see http://tinyurl.com/qczrtg.

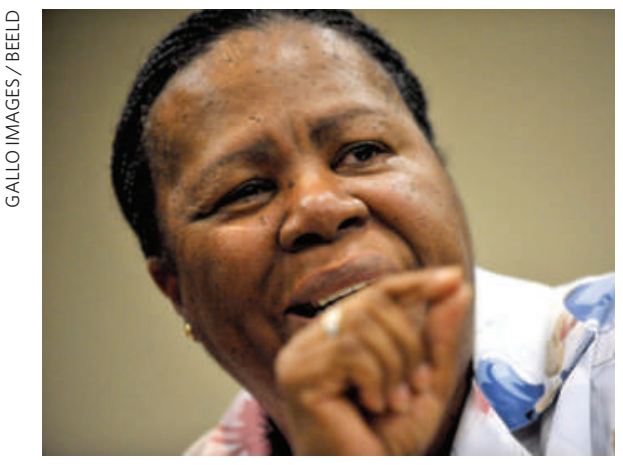

Naledi Pandor has been appointed science minister.

\section{Quiet Sun enters new sunspot cycle}

After a prolonged lull in activity, sunspots, and their associated solar storms, are on the rise again.

According to a panel of scientists led by the US Space Weather Prediction Center, part of the National Oceanic and Atmospheric Administration, a minimum in sunspot activity was passed in December 2008. In a consensus forecast on 8 May, the researchers said a new cycle of solar storms would peak in May 2013. But judging by the historical record, the recent persistence of a quiet Sun suggests that sunspot activity at this peak will be the weakest since the solar maximum of 1928.

NASA's STEREO mission spotted large regions of magnetic activity (white spots on image) on the Sun this month.

\section{University fined after safety-failure lab death}

The University of California, Los Angeles (UCLA), has been hit with a fine for multiple safety violations, following the death of a chemistry researcher in a lab fire.

The California Division of Occupational Safety and Health fined the university nearly US $\$ 32,000$ on 4 May, after the death of Sheharbano 'Sheri' Sangji. Sangji, 23, died on 16 January after being critically burned on 29 December 2008 in the Molecular Science Building.

The university was criticized for failing to train personnel in the use of dangerous chemicals, for not requiring the wearing of protective clothing and for not correcting deficient lab practices identified in an inspection last October.

Gene Block, UCLA chancellor, said in a statement that the university has embarked on a campus-wide review of laboratory safety and practices.

For a longer version of this story, see http://tinyurl. com/cj9mp8.

\section{Human space-flight review in US budget proposals}

US President Barack Obama will convene a panel of experts to evaluate the future of NASA's human space-flight programme.

The review will look at whether the International Space Station should be used past 2016, and at the architecture of Constellation, the system of rockets and capsules that will take astronauts back to the Moon. A report is expected by August.

The announcement came as part of the 7 May unveiling of Obama's full budget request for fiscal year 2010. Most science agencies received their top-line funding requests in March, but last week the

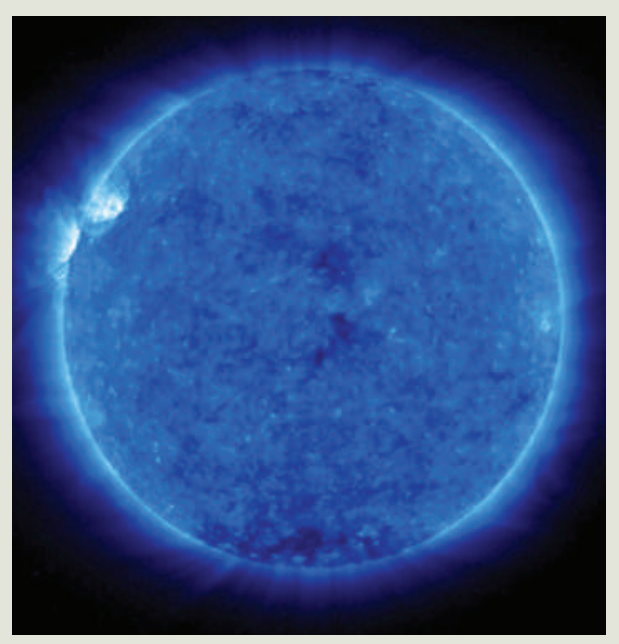

National Institutes of Health (NIH) got its number for the first time: $\$ 30.8$ billion, a $\$ 443$-million increase (or 1.4\%) over last year.

Some researchers say the rise is not enough to maintain the momentum they hope to achieve with the $\$ 10.4$-billion boost for the NIH granted in February as part of the economic stimulus package.

More than $40 \%$ ( $\$ 181$ million) of the new money requested by Obama would go to the National Cancer Institute. Across the agency, total spending on cancer research would grow by $\$ 268$ million, to $5 \%$ above 2009 levels.

For more on the US budget, see http://tiny.cc/Zdrjx.

\section{Japan to pay firms to relieve postdoc glut}

Japan's science and education ministry has announced a $¥ 500$-million (US\$5-million) plan to pay companies to hire postdoctoral students.

The scheme aims to deal with a glut of unemployed postdocs in the nation. The number of academic posts available to them has shrunk since the 1990s, as a result of government streamlining in the university system (see Nature 449, 1084-1085; 2007).

By February 2009, 17,827 unemployed postdocs had registered with the Japan Information Career Network (JREC-IN), a website hosted by the Japan Science and Technology Agency (JST) that lists science-related jobs.

Industry traditionally recruits undergraduates, but the JST plans to provide grants to around 100 companies that hire postdocs, mainly through the JREC-IN. The grants would be financed through a supplementary budget being discussed in the current parliamentary session, which is expected to end in June. 